\title{
First results of monitoring of stand structure changes in unmanaged beech stands in NP Plitvice Lakes
}

\begin{abstract}
Vladimir Novotny
Croatian Forest Research Institute, Jastrebarsko Division for Forest Management and Forest Economics Trnjanska 35, HR-10000 Zagreb, Croatia
\end{abstract}

vladon@sumins.hr
Tomislav Dubravac Dijana Vuletić

Croatian Forest

Research Institute,

Jastrebarsko

Division for Silviculture

Cvjetno naselje 41,

HR-10450 Jastrebarsko,

Croatia

Croatian Forest

Research Institute,

Jastrebarsko

Director

HR-10450

Jastrebarsko,

\begin{abstract}
Stjepan Dekanić
Croatian Forest

Research Institute,

Jastrebarsko

Division for Silviculture

Cvjetno naselje 41, HR-10450 Jastrebarsko, Croatia
\end{abstract}

Cvjetno naselje 41,

Croatia

\section{Abstract}

Background and purpose:

It is possible to monitor and study the natural growth and development of the forest ecosystems in the example of protected forest stands, which were excluded from management, and which are not under a negative influence of human activity. Therefore the aim of the research through the repeated measurements is to estimate the stand structure development on the Medvedak permanent experimental plot in the Plitvice Lakes national park area. In this paper we presented the first preliminary results of established monitoring, i.e. comparison of results of stand structure elements between two measurements (1998 and 2008). Furthermore, obtained results were compared with data from growth-yield tables for common beech stands similar characteristics as researched stand. In this case data from growth-yield tables present managed pure beech stands.

\section{Material and methods:}

The permanent experimental plot was set in 1998 in the natural stand of mountain beech forest (Lamio orvaleFagetum sylvaticae $\mathrm{Ht}$. 1938). It is in rectangular shape, dimensions $100 \times 100 \mathrm{~m}$, with subplot $60 \times 60 \mathrm{~m}$ and $30 \times 30 \mathrm{~m}$. The plot is founded according to the experimental plot setting methodology (Dubravac \& Novotny, 1992 and Novotny, 1997) extended on the ICP Forest workgroup demand. Tree crown damage assessment was repeated in 2003, and in June 2008 another measurement of basic stand structural elements was done.
Results and Conclusion:

The results in this paper show the development of the observed structural elements of the pure beech stand in the natural conditions without the management activities.

According to the results of stand structure development (shape of diameter distribution, number of trees, stand basal area and volume) and results obtained in other research at the same plot [9] (number, vitality and quality of beech young growth) it can be concluded that our stand is developing towards the optimum phase of the secondary virgin forest. Furthermore, obtained results show discrepancies in relation to managed pure beech stand from growth-yield tables.

Decrease in the number of trees, increase of the proportion of dead trees and proportion of significantly damaged trees in the monitoring period indicate the decrease of the stand vitality and health. Therefore, the question arises: Should protected forests today be absolutely left to the natural process of growth, development and dying? Since ten years is a brief period for research and conclusions about structural changes in the stand, further research efforts are necessary. They must be expanded with additional information and data from other permanent experimental plots which are also founded in other special purpose forests within project as well.

\section{Key words:}

common beech, protected forest ecosystems, growth and development, stand structure elements 


\section{INTRODUCTION}

Last few decades we are globally witnessing an increasing technological development. One of the results of that process is also a negative influence on the natural resources. Since usually selfish run after "benefit", "development", "progress" and finally "profit" causes negative phenomena, our obligation is at least to try to harmonize ecological, social, economical, and other demands with the natural development of the forest ecosystems [1].

It is well known that many of the human activities endanger forest ecosystems. Specific feature of every single ecosystem is how it reacts and how big the endurance capacity on those problems is. The growth and development of some forest ecosystems are more measurable indicators of ecological and biological influence and relationship parameters as well as anthropological activities in and around them. Protected forest ecosystems are mostly not under a negative influence of human activity, therefore the development of the wildlife as well as any other features of those ecosystems occur in natural life conditions and represent a natural development. That is the reason why such ecosystems are so significant and suitable for scientific research [214]. With help of a continuous monitoring we have a privilege to monitor and study the natural growth and development and in that way come to certain conclusions about the natural development regularities as a potential goal.

In Croatia the development research of some structure elements in protected pure beech stands is best managed in the national park The Plitvice Lakes.

Due to its natural values, the exceptionality of flora and fauna in the harmony with geomorphological figures of sedra and travertine, and because of a large number of water springs, streams, lakes and waterfalls, because of its speciality and uniqueness, the area of The Plitvice Lakes was made a national park. The park was inscribed on the UNESCO world heritage list in 1979, in recognition of its outstanding natural beauty, sensitive for natural changes and direct human activity.

Organized forestry within today's area of the national park has begun during the period of the Military Frontier in 1746. The first data of forest management in Plitvice originate in 1883, when a management plan was established in German. In 1913 "Royal forest management" made a management plan where the whole area was divided into three economic categories (A, B, C). This groundwork regulated that the $C$ - economic category including protection forest zone rules out any intervention in the forests [4].
Development of the forest ecosystems in Plitvice Lakes national park area was the object of research of many authors. After conducted typological researches in 1976, Hren [15] indicates that applied management method was not favorable for the regeneration of the stands. Cestar et al. established four forest reserves (1,347 ha) in the Plitvice Lakes national park from the 1976 to 1986, "Medveđak" in 1976 [16], "Čorkova uvala-Čudinka" in 1977 [17], "Kik-Visibaba" in 1979 and "Riječica-Javornik" in 1986 [18] with the aim of monitoring the development of forests in natural conditions in the national park. In 1984 Klepac suggested an active forest protection [3], and in 1994 recommended ecological forest management that should provide a permanent natural forest regeneration [4]. Lukić and Kružić (1992) researched development of common beech on the Medveđak permanent plot [19]. Krejči and Dubravac (2001) researched the conditions for natural forest regeneration [8]. Dubravac et al. (2004) studied development of structure and continued with researches of natural forest regeneration on two experimental plots in forest reserve Medveđak [9].

Permanent experimental plot in the national park area, that is, inside the "Medveđak" forest reservation, was founded in 1998 with the aim of researching in the "Forest Growth and Development for special means" multidisciplinary project. Project is conceived as a permanent monitoring of special purpose forests, which primarily include forests of national parks and nature parks. Beside from monitoring establishment, project objectives are also studying and analyzing growth and development of special purpose forests and researching of structural changes of those stands.

The basic hypothesis of this paper is that some changes occurred without an anthropological influence in a certain period of time, and that a tree as a unit, and a forest as a whole were growing in natural conditions. The aim of the research is to estimate the stand structure development within the natural development regularities of pure beech stand via repeated measurements on the permanent experimental plot.

In this paper we presented the first preliminary results of established monitoring, i.e. comparison of results of stand structure elements between two measurements (1998 and 2008). Comparison the data of first (1998) and second measurements (2008) gave inside into diameter and height growth, as well as volume and basal area increment during the last ten years.

\section{MATERIAL AND METHODS}

Forest reservation "Medveđak" is situated in the north east part of the national park "The Plitvice Lakes" and represents a part of a vast complex of 
beech forests. The whole area of the Plitvica Lakes is abundant mostly with the forest community of mountain beech forest [20].

A very important postulate in choosing a site for placing the permanent experimental plot was finding a stand of very homogenous ecological and structure characteristics, as well as beech density as a researched tree species above 0,8 which is classified to normal stands according to the Forestry management regulations [21]. According to Miletic [22] the stand structure, in the widest sense, is formed out of all elements that make wood mass and dispose it in space.

The plot is setin a natural mountain beech forest stand (Lamio orvale-Fagetum sylvaticae Ht. 1938), of the I-D10 ecological management type. The plot coordinates are $\mathrm{N}=44^{\circ} 53^{\prime} 09^{\prime \prime} \mathrm{E}=15^{\circ} 38^{\prime} 01^{\prime \prime}$, with the $570 \mathrm{~m}$ altitude, and the terrain is rich with karst sinkholes. The stand represents the pure beech stand from seed with clumped tree formation. The single-layer stand has a uniform structure, full crown closure and medium quality (Figure 1, Figure 2B).

The permanent experimental plot was formed according to the experimental plot establishment methodology applied in the "Ecological- Economic Forest Type Valence" multidisciplinary project $[23,24]$, extended with the demands of the ICP forest workgroup about minimal size on which measuring and experimental taking can take place presented in horizontal plain.

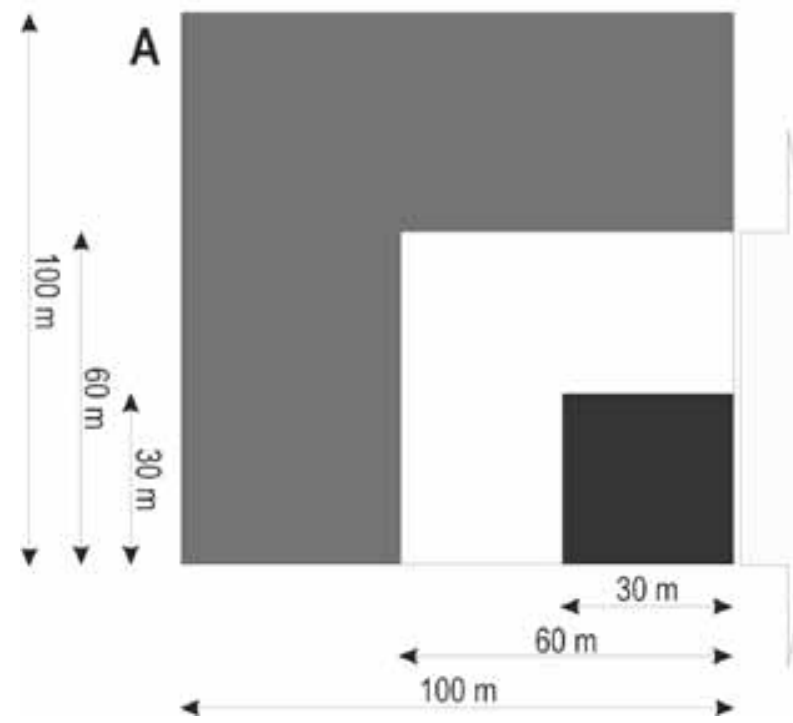

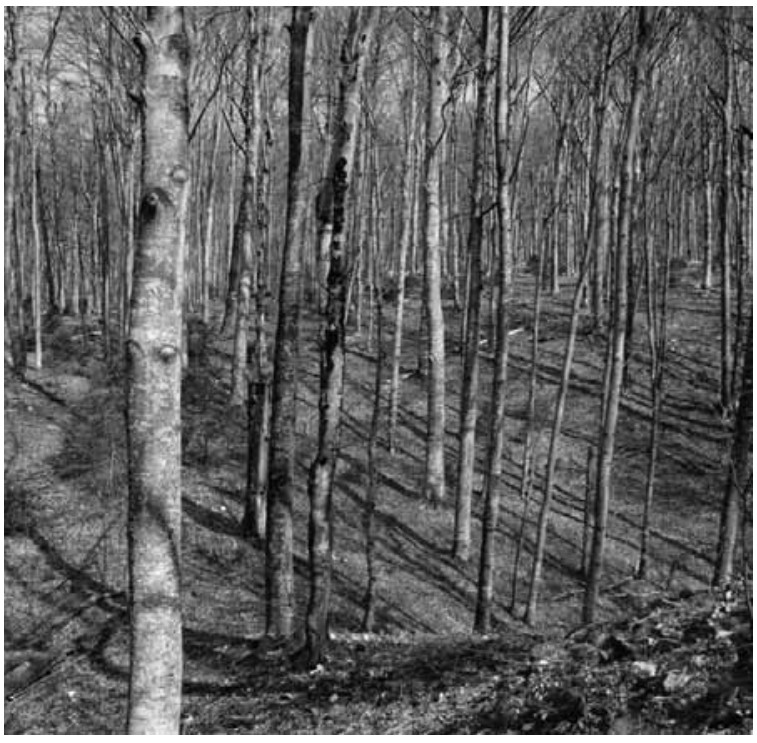

FIGURE 1

Pure beech stand on permanent experimental plot "Medveđak"

The experimental plot is in rectangular shape with dimensions $100 \times 100 \mathrm{~m}$, and $60 \times 60 \mathrm{~m}$ and $30 \times 30 \mathrm{~m}$ subplots (Figure 2 ).

While placing the plot in 1998 every tree has been permanently tagged with a colour, which is, named with a number. Two mutually perpendicular

\section{FIGURE 2}

Shape and size of permanent experimental plot $(A)$ and $3 D$ visualization of stand on $60 \times 60 \mathrm{~m}$ subplot in software EnVision (B) 
diameters at breast height $\left(\mathrm{dbh}_{1}, \mathrm{dbh}_{2}\right)$ were measured to all trees with diameter at breast height above $10 \mathrm{~cm}$ which gave the base for calculating the average diameter at breast height (dbh). The tree height $(h)$ and stem height $\left(h_{d}\right)$ were measured to every tree on the permanent experimental plot. Tree age was determined by counting the tree rings on three stumps in the diameter class of mean basal area tree and one stump per diameter classes above and below the diameter class of mean basal area tree. Stand age was then calculated as the arithmetic mean of those five tree ages. The tree crown damage assessment was made according to the method prescribed by ICP Forests. For the trees within the $60 \times 60 \mathrm{~m}$ map of the crown projected areas was made, and the stand was visualized in the software package EnVision (USDA Forest Service) (Figure 2B). For the purpose of the stand visualization terrain was spatially modelled in ArcMap (ESRI) software using the terrain heights measured by LaserAce 300 measurement device.Tree crown damage assessment was repeated in 2003, and in June 2008 there was another measurement of the necessary stand elements $\left(\mathrm{dbh}_{1}, \mathrm{dbh}_{2}, \mathrm{~h}\right)$ on the permanent experimental plot. Also, to every tree within the $60 \times 60 \mathrm{~m}$ plot was given a position in the location. Azimuth was determined by a compass and the distance from the plot centre with a distance meter. This way one can get an insight in the spatial formation of trees on the subplot.

All field data of both measurements are registered in the Ecological Management Types of the Republic of Croatia data base [25]. Field data analysis, especially of the first and the second measurement, as well as registering the average diameter at breast height of every measured beech tree in a programme made by means of Excel 2000 professional programme package, produced a beech tree number distribution according to $5 \mathrm{~cm}$ thickness degrees. It also presents an overall distribution of tree numbers per hectare on the permanent experimental plot. By tree number distribution per hectare and a formula for basal area a distribution of beech basal area per hectare was obtained, that is, a distribution of the whole basal area per hectare. In order to obtain a volume distribution, i.e. beech volume per hectare, a tree volume tables were calculated for common beech on the experimental plot, both for the first and the second measurement.

The tables were constructed by parameters $b_{0}$ and $b_{1}$ of fitted height curves by the Mihajlov formula and $a, b$ and $c$ parameters for common beech from wood volume tables [26]. A tree volume as a diameter at breast height and tree height function is calculated by the Schumacher-Hall formula. Arithmetic mean $(\bar{x}$ ), standard deviation (s), standard error $\left(s_{\bar{x}}\right)$, variation coefficient $(C V)$, and slantness coefficient $\left(B_{1}\right)$ and flatness coefficient $\left(B_{2}\right)$ as important biometrical indicators are calculated based on measured data for both measurements [24]. Obtained results were compared with data from growth-yield tables for common beech stands relevant to researched stand. In this case data from growth-yield tables present managed pure beech stands.

\section{RESULTS AND DISCUSSION}

According to the results of the tree analysis which were performed in 1998, the age of the mountain beech stand on the given permanent experimental plot in the foundation year is 147 years.

The Table 1 shows the total number of beech trees $(\mathrm{N})$, basal area $(\mathrm{G})$ and volume $(\mathrm{V})$ per hectare on the experimental plot in 1998 and 2008.

Average diameter at breast height (dbh), tree height (h) and volume (v) in both measurements are shown in Table 2 .

\section{TABLE 1}

Stand structure elements of first (1998) and second (2008) measurements

\begin{tabular}{|c|c|c|c|}
\hline \multirow{2}{*}{ Measurement year } & $\mathrm{N}$ & $\mathrm{G}$ & $\mathrm{V}$ \\
\cline { 2 - 4 } & $\mathrm{N} / \mathrm{ha}$ & $\mathrm{m}^{2} / \mathrm{ha}$ & $\mathrm{m}^{3} / \mathrm{ha}$ \\
\hline 1998 & 301 & 43,11 & 656,41 \\
\hline 2008 & 291 & 45,68 & 803,07 \\
\hline
\end{tabular}

\section{TABLE 2}

Average values of diameter at breast height, basal aera and volume of beech trees of both measurements

\begin{tabular}{|c|c|c|c|c|}
\hline \multirow{2}{*}{ Measurement year } & $\mathrm{dbh}$ & $\mathrm{h}$ & $\mathrm{g}$ & $\mathrm{v}$ \\
\cline { 2 - 5 } & $\mathrm{cm}$ & $\mathrm{m}$ & $\mathrm{m}^{2}$ & $\mathrm{~m}^{3}$ \\
\hline 1998 & 39,3 & 26,9 & 0,14 & 2,24 \\
\hline 2008 & 41,1 & 31,7 & 0,16 & 2,47 \\
\hline
\end{tabular}


Distribution of the total number of common beech trees per hectare arranged by $5 \mathrm{~cm}$ diameter degrees in the foundation year and in 2008 is shown in the Figure 3.

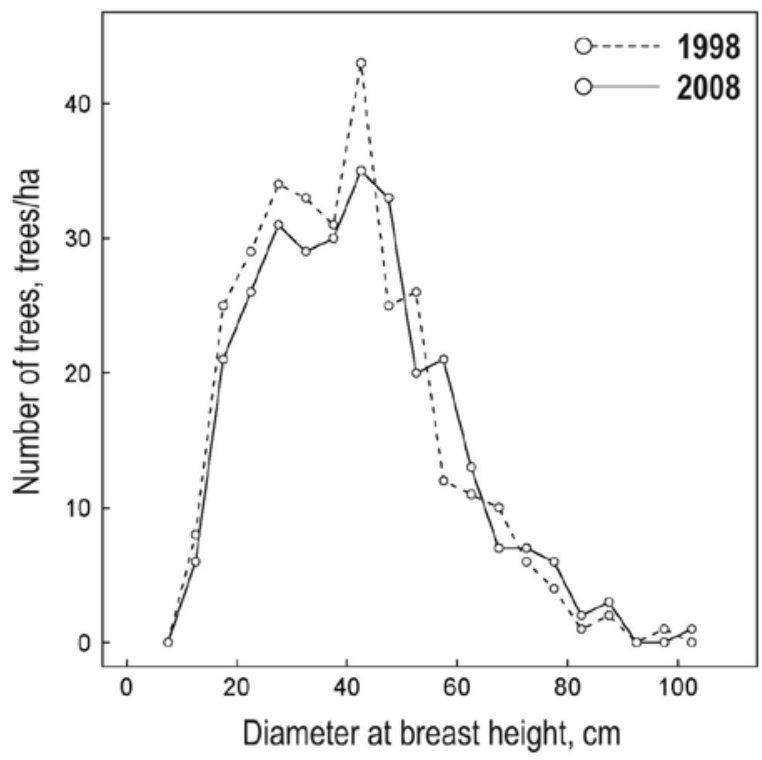

FIGURE 3

Diameter distributions of beech trees per hectare in both measurements

Stand height curves that represent stochastic dependence of the tree height by diameter at breast height (dbh) are fitted with Mihajlov formula and shown in the Figure 4. Parameters of fitted stand height curves for both measurements are shown in the Table 3.

TABLE 3

Stand structure elements for Common beech according to growth-yield tables [26]

\begin{tabular}{|c|c|c|c|}
\hline \multirow{2}{*}{$\begin{array}{c}\text { Site } \\
\text { quality }\end{array}$} & $\mathrm{N}$ & $\mathrm{G}$ & $\mathrm{V}$ \\
\cline { 2 - 4 } & $\mathrm{N} / \mathrm{ha}$ & $\mathrm{m}^{2} / \mathrm{ha}$ & $\mathrm{m}^{3} / \mathrm{ha}$ \\
\hline I & 117 & 32,7 & 646 \\
\hline II & 145 & 31,9 & 582 \\
\hline III & 186 & 31,3 & 505 \\
\hline IV & 223 & 29,6 & 413 \\
\hline
\end{tabular}

Tree volume tables were calculated by $b_{0}$ and $b_{1}$ parameters of the fitted stand height curves with the Mihajlov formula and $a, b$ and $c$ parameters for

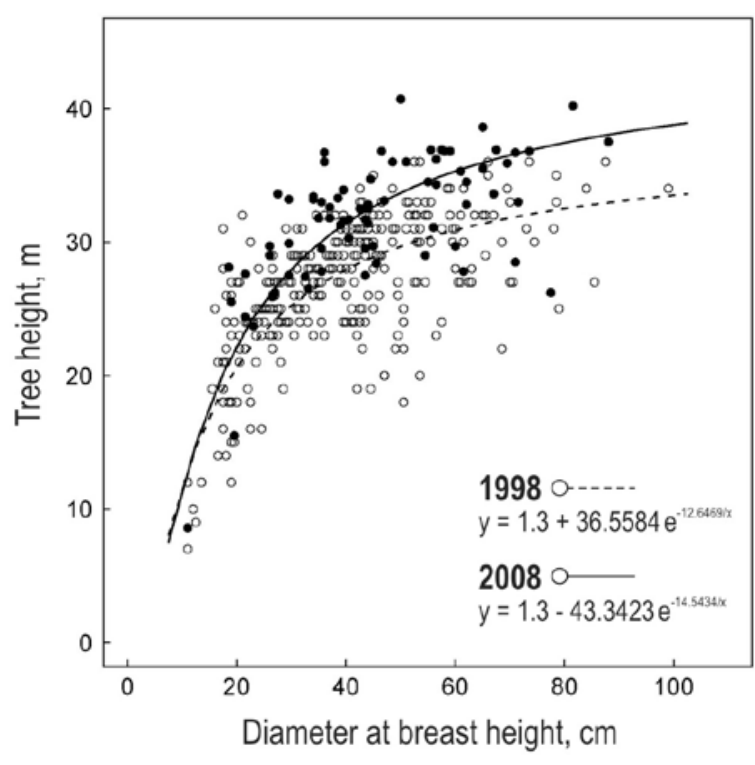

FIGURE 4

Stand height curves of common beech superimposed on measured tree heights in both measurements

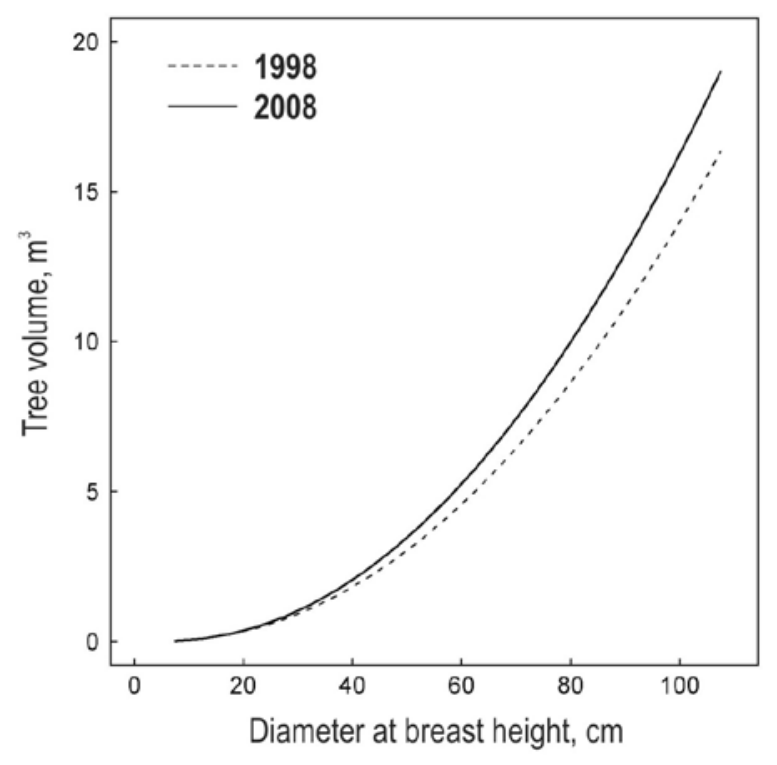

FIGURE 5

Tree volume tables in 1998 and 2008

Common beech according to Špiranec [26] were calculated by Schumacher-Hall formula and they are shown in the Figure 5.

Considering the stand age, a positive trend of diameter at breast height, tree height, basal area and tree volume development is expected as well as visible, both individually and summary. The tree 
TABLE 5

Crown damage of a common beech on the monitored plot sample

\begin{tabular}{|c|c|c|c|c|c|}
\hline \multirow{2}{*}{$\begin{array}{c}\text { Measurement } \\
\text { year }\end{array}$} & \multicolumn{4}{|c|}{ Crown defoliation degree } & $\begin{array}{c}\text { Significance } \\
\text { damage }\end{array}$ \\
\cline { 2 - 6 } & $0-10 \%$ & $11-25 \%$ & $26-60 \%$ & $>60 \%$ & $(\%)$ \\
\hline 1998 & 84,1 & 10,3 & 4,5 & 1,1 & 5,6 \\
\hline 2003 & 67,0 & 15,9 & 6,8 & 10,3 & 17,1 \\
\hline
\end{tabular}

number decrease is also both expected and logical in the given time. It results with also a logical positive shift of the observed elements stand height curves or tariff sequences. Therefore it can be said that diameter, height and volume increase is evident.

Comparing the values of the researched elements to the data from yield tables according to Špiranec [26] for a 157 year old beech with site quality from I to IV (Table 4), a significant deviation is visible. The differences in comparison of tree numbers, basal area and volume per hectare are significant, while the comparison differences of average diameter at breast height and medium stand tree height are smaller. At the same time the values of the diameter at breast height and the researched stand height are almost identical to the average values for the 159 year old beech on the IV site quality, according to Špiranec [26].

Observing the total volume (Table 1) as tree number function, diameter at breast height and tree height and its development as a time function, one can come to a conclusion that there is a large current annual volume increment $\left(14,7 \mathrm{~m}^{3} / \mathrm{ha}\right)$ as well as its increase percentage $(2,23 \%)$ considering the age of the researched stand.

Considering the fact that the role of the researched stand is not productive but protective, it is more interesting to observe the health condition and vitality. When the results obtained in this research are observed in that way, the conclusions are that in the period of the first as well as the second measurement, there are a too large number of trees and a large volume in the researched area. Therefore the obtained results, about the ground concealment with trees of 96\% [8] and about the annual average 1 dead fallen tree and 3,6 dead trees (Figure 6) between two measurements are logical.

Comparing the initial status and the status after the second measurement based on the measured data, we get an insight about the participation of fallen and dead trees in reference to initial state. Decreasing in number of live trees and increased share of dead trees are most noticeable in the range of diameter degree from $17,5 \mathrm{~cm}$ to $42,5 \mathrm{~cm}$, and these are trees that are beneath the canopy of dominant trees.
The confirmation of these data is visible also in crown damage analysis in the monitoring period from 1998 to 2003 (Table 5).

An increasing number of considerably damaged trees in a five year period, $5,6 \%$ to $17,1 \%$ can be justified by a fact that those trees, to a higher extent, are under the crowns of the dominant trees [9]. Nevertheless the fact is surely concerning and alarming. Due to the competition among trees and without management activities and interventions, the trees die out in a natural process. In our research the case is the same, but it also emphasizes an undeniable fact that it significantly reduces vitality and health condition of the stand.

According to the results of stand structure development (shape of diameter distribution, number of trees, stand basal area and volume) and results obtained in other research at the same plot [9] (number, vitality and quality of beech young growth) it can be concluded that our stand is developing towards the optimum phase of the secondary virgin forest.

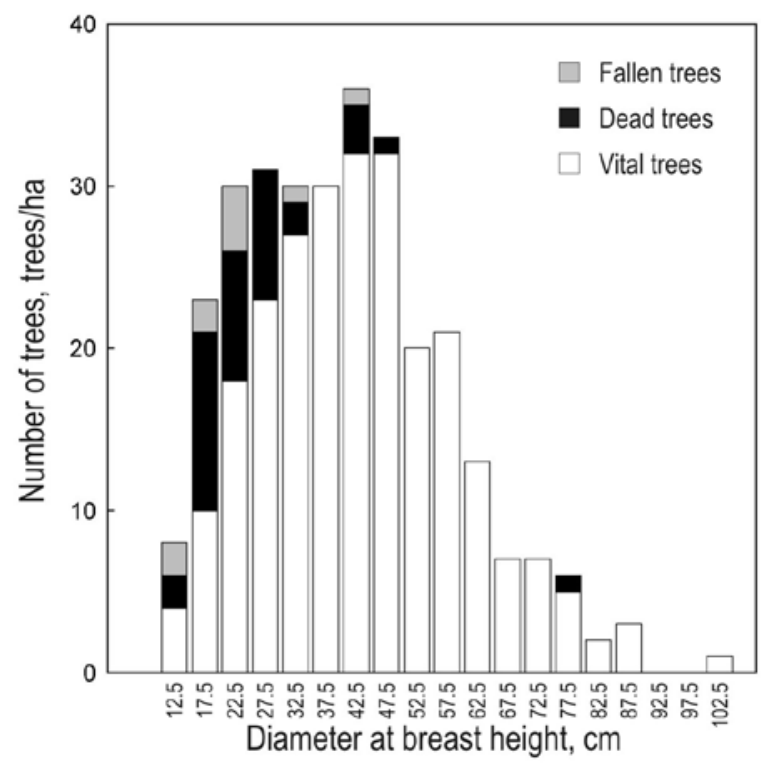

FIGURE 6

Number of dead and fallen trees in the total tree number between the two measurements 
As already mentioned, Lukić and Kružić [19] also researched development of stand structural elements on permanent plot in pure beech stand in the forest reserve Medveđak. Results from first (1980) and second measurement (1988) showed no change of the unimodal character of the diameter distribution of beech trees. Furthermore, the number of trees decreased by $6,5 \%$ (29 trees), basal area was increased by $6,94 \%\left(3,16 \mathrm{~m}^{2} / \mathrm{ha}\right)$ and volume by $12,49 \%(60,62$ $\mathrm{m}^{3} / \mathrm{ha}$ ). Current annual volume increment of $7,58 \mathrm{~m}^{3} /$ ha $(1,56 \%)$ was found. Juriček [27] also found similar trends in the development of beech stand structural elements. From 1980 to 2004 the number of trees decreased by $25,89 \%$, basal area was increased by $5,82 \%$ and total volume by $31,96 \%$. Current annual volume increment amounted to $9,08 \mathrm{~m}^{3} / \mathrm{ha}$ (Table 6).

Hren [15] conducted research in pure beech virgin forest in optimal phase in Ramino korito where he found even-aged structure in all researched stands. According to his research stand density varied from 371 to 524 trees per hectare, stand basal area was between 45,68 and $49,05 \mathrm{~m}^{2} / \mathrm{ha}$, stand volume amounted from 486,91 to $654,89 \mathrm{~m}^{3} / \mathrm{ha}$, and the Dbh of mean beech trees measured from 29,5 to $39,9 \mathrm{~cm}$ (Table 6).

Mešković [28] researched a stand structure of virgin beech forest "Mačen do" (BIH) in different development phases. Results for "early" and "late" optimum phases correspond well with the results obtained in our research (Table 6). Table 6 summarizes some of the published results from the research conducted in optimum phase of virgin beech forests in the SEE region, in the terms of stand density N, stand basal area $G$, stand volume $V$ and stand current annual volume increment $\left(i_{v}\right)$. For some of presented results their repeated measurements are also shown.

\section{CONCLUSIONS}

The research area is under a state and international protection. The development of the stand researched structure elements was observed as a time function in almost natural development conditions, with only small or none anthropogenic influence. According to the results of stand structure development (shape of diameter distribution, number of trees, stand basal area and volume) and results obtained in other research at the same plot [9] (number, vitality and quality of beech young growth) it can be concluded that our stand is developing towards the optimum phase of the secondary virgin forest.Comparing the obtained values of the researched structure stands elements to the data from yield tables for managed pure beech stands a significant deviation is visible. Since our researched stand is a special purpose forest whose function is primarily protective rather than productive, besides structural stands elements it is important to observe the health and vitality of stand as well. The

TABLE 6

Results of stand structure elements of research conducted in optimum phase of virgin forests

\begin{tabular}{|c|c|c|c|c|c|c|c|c|}
\hline \multirow[t]{2}{*}{ Reference } & \multirow[t]{2}{*}{ Research area } & \multirow{2}{*}{$\begin{array}{c}\text { Measure- } \\
\text { ment } \\
\text { year }\end{array}$} & \multirow{2}{*}{$\begin{array}{c}\text { Develop- } \\
\text { ment } \\
\text { phase } \\
\text { of virgin } \\
\text { forest }\end{array}$} & $\begin{array}{c}\text { Taxa- } \\
\text { tion limit } \\
\text { (>dbh) }\end{array}$ & $\mathrm{N}$ & G & V & $\mathrm{i}_{\mathrm{v}}$ \\
\hline & & & & $\mathrm{cm}$ & trees/ha & $\mathrm{m}^{2} / \mathrm{ha}$ & $\mathrm{m}^{3} / \mathrm{ha}$ & $\mathrm{m}^{3} / \mathrm{ha}$ \\
\hline [15] & Ramino korito & 1972 & Optimum & 7,5 & $371-524$ & $\begin{array}{c}45,68- \\
49,05\end{array}$ & $\begin{array}{c}486,91- \\
654,89\end{array}$ & - \\
\hline [19] & Medvjeđak_1 & 1990 & Optimum & 7,5 & 447 & 42,37 & 424,64 & - \\
\hline [19] & Medvjeđak_1 & 1998 & Optimum & 10 & 418 & 45,53 & 485,26 & 7,58 \\
\hline$[27]$ & Medvjeđak_1 & 2004 & Optimum & 10 & 332 & 43,98 & 653,25 & 9,08 \\
\hline $\begin{array}{c}\text { This } \\
\text { research }\end{array}$ & Medvjeđak_2 & 1998 & Optimum & 10 & 301 & 43,11 & 656,41 & - \\
\hline $\begin{array}{c}\text { This } \\
\text { research }\end{array}$ & Medvjeđak_2 & 2008 & Optimum & 10 & 291 & 45,68 & 803,07 & 14,7 \\
\hline [28] & Mačen do & $\begin{array}{l}2003 \\
2004\end{array}$ & $\begin{array}{c}\text { Early } \\
\text { optimum }\end{array}$ & 5 & 546 & 43,60 & 635,67 & 9,08 \\
\hline$[28]$ & Mačen do & $\begin{array}{l}2003 \\
2004\end{array}$ & $\begin{array}{c}\text { Late } \\
\text { optimum }\end{array}$ & 5 & 782 & 56,18 & 890,25 & 9,54 \\
\hline
\end{tabular}


results observed in ten-year period show a decrease in the number of trees, increase the proportion of dead trees and increase proportion of significantly damaged trees which then indicate that vitality and health of the stand is significantly decreased.

Consequently we must ask ourselves: Should protected forests today be absolutely left to the natural process of growth, development and dying? There is surely an answer to that, and the task of the forest science especially, is to present it in the best interests of forest and people existence, and of the natural forest resource preservation with a help of future research results in that area. In the seeking of answers, continuous monitoring surely can help us. In this preliminary research monitoring was proved to be a good method for monitoring and analyzing the growth and development of special purpose forests. Since ten years is a brief period for research and draw conclusions about structural changes in the stand, especially because our observed stand is an old stand in which structural changes occur slowly, it is necessary to proceed with further continuous measurements.

Furthermore, research must be expanded with additional information and data from other permanent experimental plots which are also founded in other special purpose forests within project as well.

\section{REFERENCES}

1. GLAVAČ V 1999 Uvod u globalnu ekologiju. Državna uprava za zaštitu prirode i okoliša; "Hrvatske šume", Javno Poduzeće za gospodarenje šumama i šumskim zemljištima u Republici Hrvatskoj, Zagreb, p 211

2. CESTAR D, HREN V, KOVAČEVIĆ Z, MARTINOVIĆ J, PELCER Z 1976 Ekološko-gospodarski tipovi šuma na području Nacionalnog parka Plitvička jezera. Rad Šumar Inst 50: 1-76

3. KLEPAC D 1984 Principi uređivanja šuma Nacionalnog Parka "Plitvička jezera". Šum list 108 (7-8): 319-335

4. KLEPAC D 1994 Ekološko uređivanje šuma u Nacionalnom Parku "Plitvička jezera". Plitvička jezera nacionalno dobro Hrvatska svjetska baština, Zagreb, p 69-80

5. POŠTENJAK K, GRADEČKI M 1994 Stojbinske prilike šuma N.P. "Risnjak". Zbornik radova, Crni lug, p 34-46

6. MATIĆ S, ORŠANIĆ M, ANIĆ I 1995 Strukturne osobine šuma otoka Mljeta. Prirodne značajke i društvena revitalizacija otoka Mljeta, Zagreb, p 297-303

7. MATIĆ S, ORŠANIĆ M, ANIĆ I 1996 Bukove šume Hrvatske i njihovo mjesto u kompleksu šuma središnje i jugoistočne Europe. In: B. Mayer (ed) Unapređenje proizvodnje biomase šumskih ekosustava, Šumarski fakultet Sveučilišta u Zagrebu i Šumarski institut Jastrebarsko, Zagreb, p 113-124

8. KREJČI V, DUBRAVAC T 2001 Mogućnost obnove šuma Nacionalnih parkova. Rad Šumar Inst 36 (2): 113-122

9. DUBRAVAC T, KREJČl V, VRBEK B 2004 Stanje strukture i mogućnost prirodne obnove čistih bukovih sastojina $u$ šumskom rezervatu "Medvjeđak". Savjetovanje u povodu 55 godina Nacionalnog parka Plitvička jezera i 25 godina Plitvičkih jezera na listi svjetske prirodne baštine, Plitvička jezera, Plitvički bilten 6: 179-200

10. VRBEK B, PILAŠ I, ŠOJAT V, MAGDIĆ N 2004 Utjecaj kiselih kiša na šumu i na tlo u Nacionalnom parku Plitvička jezera. Savjetovanje u povodu 55 godina Nacionalnog parka Plitvička jezera i 25 godina Plitvičkih jezera na listi svjetske prirodne baštine, Plitvička jezera, Plitvički bilten 6: 141-154

11. DUBRAVAC T, VULETIĆ D, VRBEK B 2005 Natural reforestation and future of beech and fir forests in the Risnjak NP. Period biol 107: 73-79

12. DUBRAVAC T, DEKANIĆ S, VULETIĆ D 2006 Stanje šuma bukve i jele u Nacionalnom parku "Risnjak" - aktivna ili pasivna zaštita?. Zbornik radova, Međunarodna naučna konferencija Gazdovanje šumskim ekosistemima Nacionalnih parkova i drugih zaštićenih područja, Jul 05-08, Jahorina-Tjentište, Bosna i Hercegovina, p 191-203

13. DUBRAVAC T, ČAVLOVIĆ J, ROTH V, VRBEK B, NOVOTNY V, DEKANIĆ S 2007 The structure and possibility of natural regeneration in managed and non-managed beech and fir forests in Croatia. Period biol 109: 21-27
14. MATIĆ S 2009 Veza između prirodnog gospodarenja i životnih faza u razvoju prašume. Zbornik radova znanstvenog skupa "Prašumski ekosustavi dinarskoga krša i prirodno gospodarenje šumama u Hrvatskoj, HAZU, p 9-19

15. HREN V 1972 Ramino korito- prašuma bukve. Šum list 96 (9-10): 315-324.

16. CESTAR D, HREN V, KOVAČEVIĆ $Z$, MARTINOVIĆ J, PELCER Z, BEZAK K, KRZNAR A, LINDIĆ V, VRBEK B, KREJČI V 1982 Prirodni šumski rezervat Medveđak. Rad Šumar Inst 50: 1-76

17. CESTAR D, HREN V, KOVAČEVIĆ Z, MARTINOVIĆ J, PELCER Z, BEZAK K, KREJČI V, KRZNAR A, LINDIĆ V, MEDVEDOVIĆ J, VRBEK B 1983 Prirodni šumski rezervat Čorkova uvala-Čudinka. Rad Šumar Inst 53: 1-44

18. CESTAR D, HREN V, KOVAČEVIĆ $Z$, MARTINOVIĆ J, PELCER Z, BEZAK K, KREJČI V, KRZNAR A, LINDIĆ V, MEDVEDOVIĆ J, VRBEK B 1984 Prirodni šumski rezervat Rječica-Javornik. Rad Šumar Inst 58: 41-76

19. LUKIĆ N, KRUŽIĆ T 1992 Razvoj obične bukve (Fagus sylvytica L.) na trajnoj plohi Medveđak. Šum list 116 (11-12): 510-513

20. CESTAR D, HREN V, KOVAČEVIĆ $Z$, MARTINOVIĆ J, PELCER Z, BEZAK K, KRZNAR A, LINDIĆ V, VRBEK B, KREJČI V 1982 Prirodni šumski rezervat Medveđak. Rad Šumar Inst 50:1-76

21. NOVOTNY V, BENKO M, VRBEK B 1999 The development od structural elements of floodplain forests (Genisto elatae-Quercetum roboris $\mathrm{Ht}$. 1938) in Slavonia. Ecology 18(1): 47-58

22. MILETIĆ Ž 1950 Osnovi uređivanja prebirne šume, knjiga 1. Beograd

23. DUBRAVAC T, NOVOTNY V 1992 Metodologija tematskog područja uzgajanje šuma-rast i prirast (primjenjena $u$ multidisciplinarnom projektu Ekološko ekonomske valencije tipova šuma). Rad Šumar Inst 27(2): 157-166

24. NOVOTNY V 1998 Pomak osnovnih sastojinskih elemenata u vremenu između dviju izmjera u zajednici Carpino betuli-Quercetum roboris/Anić 1959/Rauš 1969. Rad Šumar Inst 33(1): 1-46

25.BEKIĆ Z, HUNJET D, MILINOVIĆ M, KRZNAR A 1992 Informacijski sustav za praćenje pojava i procesa u ekološko-gospodarskim tipovima šuma Republike Hrvatske. Rad Šumar Inst 27(2): 195-202

26. ŠPIRANEC M 1975 Drvnogromadne tablice za hrast, bukvu, ob.grab i pitomi kesten. Rad Šumar Inst 22: 1-262

27.JURIČEK M 2005 Razvoj šumske vegetacije na trajnim pokusnim plohama NP Plitvička jezera. Diplomski rad, Faculty of forestry, University of Zagreb, p 78

28. MEŠKOVIĆ E 2007 Taksacioni elementi bukovih sastojina prašumskog tipa na lokalitetu "Mačen do" g.j. "Gostelja Kladanj". Naše šume 10-11: 3-15 